\title{
Bamboo Furniture Design Development with Used Newspaper as an environmentally friendly product in Sleman Regency
}

\author{
Kristian Oentoro $^{1 *}$, Wiyatiningsih Wiyatiningsih ${ }^{2}$ \\ ${ }^{1}$ Department of Product Design, Universitas Kristen Duta Wacana, Indonesia \\ ${ }^{2}$ Department of Architecture, Universitas Kristen Duta Wacana, Indonesia \\ *Corresponding author.Email: kristian@staff.ukdw.ac.id
}

\begin{abstract}
The combination of bamboo material and used newspaper is an idea to increase innovation and product creation for Small Medium Enterprises in the Sleman Regency. Bamboo as a natural and local material is widely used by Indonesians for various needs, especially for traditional crafts and furniture. Bamboo processing skills have been traditionally developed in the areas where bamboo plants are plentiful, particularly in some villages in Sleman Regency. Bamboo furniture design development plays an important role in increasing competitiveness among the craft centers in Sleman Regency. Therefore, this study aims to develop bamboo furniture designs with a combination of used newsprint material. The used newsprints were chosen due to recycled material application. It is processed using the roll technique in this combination material. This research applies the generic product method and explains the iterative design process of bamboo and newspaper easy chair design. It also produces three bamboo easy chairs prototypes that apply a knock-down concept and a flat package. Through the third stage of prototyping, the bamboo chair design can achieve a volume weight of $26.4 \mathrm{~kg}$ (actual weights $5.8 \mathrm{~kg}$ ) with 5 modules and 10 nuts and bolts. Additionally, the combination of bamboo and newspaper is also considered as added value for sustainable bamboo furniture. Besides utilizing recycled materials, this easy chair design also supports the ease of shipping products to adapt to online sales trends during the COVID-19 pandemic.
\end{abstract}

Keywords: Bamboo, Combination, Furniture, Newspaper

\section{INTRODUCTION}

One of the ways to develop furniture design innovation is to combine materials. However, it also depends on some design development topics about the properties of existing material and new material application [1]. In this study, the process of bamboo and used newspaper combination becomes the main topic of furniture design development including some product design considerations related to environmental and technical issues in product shipping. The material replacement of some parts in bamboo furniture also becomes the design development process in search of how to apply proper newsprint material on bamboo furniture. Moreover, both of the materials are considered as environmentally friendly materials. Bamboo is a renewable natural material [2], while used newspapers are a recycled alternative material that is expected to strengthen an environmental issue in design furniture. Used newspapers were also chosen in this study because this material is a type of paper waste that is easily found in our environment. As an aesthetic natural material in Indonesia, the use of bamboo in furniture design needs to be developed to increase the competitiveness of local products, especially bamboo crafts and furniture of SMEs in Sleman Regency.

In various areas of Indonesia's forests, there are 161 species of bamboo plants, which is equal to $11.5 \%$ of the world's bamboo species [3]. As a natural and local material in Indonesia, bamboo is also widely used for various needs and creations, especially for traditional handicrafts and furniture. Therefore, the utilization of bamboo material in rural areas also becomes a unique part of Indonesian art and culture. In Java, there is a traditional bamboo bench named lincak (Javanese) that has become the icon of 
traditional bamboo furniture in some villages. In rural areas where bamboo plants are plentiful, varied traditional bamboo processing skills and tools are greatly developed. Bamboo material also becomes an economic potential for developing the creative industries, particularly in the craft sub-sector.

One of the regencies that have bamboo potential is Sleman Regency, which is located in the Special Region of Yogyakarta. Most of the bamboo craft industries in Sleman Regency are Small and Medium Enterprises (SMEs) that become the economic potential for community empowerment. Based on data from the Government of Sleman [4], there are 1.759 SMEs in the bamboo craft industry in Sleman Regency that employ 3.497 workers. Sleman Regency officially has several bamboo furniture craft centers spread in 5 districts, that are Minggir, Moyudan, Godean, Seyegan, dan Mlati [5]. Due to the good economic potential of the bamboo industry in Sleman Regency, bamboo material is designated as a leading commodity of Non-Timber Forest Products (NTFPs) through the Sleman Regent Decree No. 306/Kep.KDH/A/2013. Various bamboo handicrafts have been categorized into four types, (1) furniture, (2) woven products, (3) home furnishing, and (4) souvenirs. Compared to the other of the handicrafts types, bamboo furniture products have a higher selling value in the market. The following pictures are the traditional furniture products commonly seen in Sleman bamboo craft center.

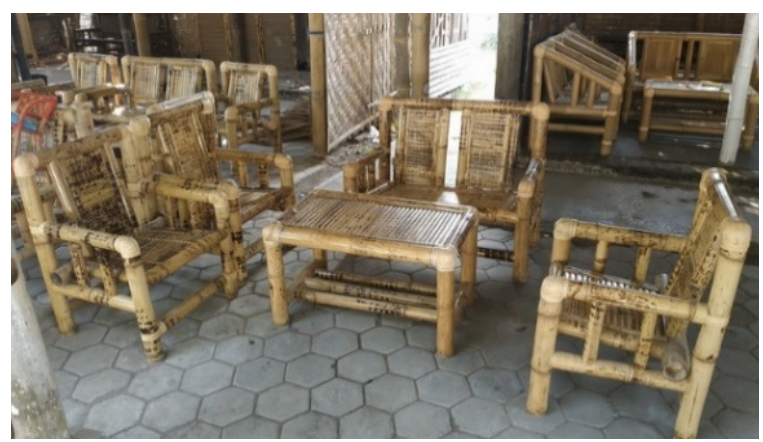

Figure 1. Bamboo Craft Products in Sleman Regency

The bamboo furniture design development in Sleman Regency has become the need of industry to increase competitiveness in the market. Since early March 2020, many crafts and furniture exhibitions at the national and international levels have been canceled due to the COVID-19 pandemic. Consequently, it also makes many bamboo industries in Sleman Regency experience a significant decrease in the number of orders, even cancellation of ongoing orders. Product design innovation is the key for bamboo industries to adapt to the changing demands of today's furniture market. One of the product design challenges is how bamboo furniture meets the needs of the online market. In addition to being able to dominate the market, research and design development also potentially increase the innovation in making bamboo furniture more sustainable. In this furniture design development case study, used newsprint becomes an alternative material combined with bamboo. This design idea emerges to utilize the paper waste in our environment to have commercial value.

The application of used newsprint in the furniture structure is potentially feasible to use based on previous material research [6]. The utilization of used newsprint as the wasted material also supports the concept of environmentally friendly products in bamboo traditional furniture. The aim of this research is to design the furniture with a combination of bamboo and newsprint material which is appropriate for current market developments. Considering the level of complexity of the furniture construction and market viability, the chair design was chosen to be developed in this study. The bamboo chair design is a type of furniture which is popular in many bamboo craft centers in Sleman Regency. Therefore, this research and development of bamboo chair design were also conducted in collaboration with the Gentan bamboo craft center in Margomulyo Village, Sleman Regency. This bamboo craft center is a communitybased SME that has skilled craftsmen and a potential market segment

\section{METHOD}

This bamboo chair design development is the design and material exploration based on experimental study and iterative processes. Material exploration also becomes the reflective practice of product designers to gain experiential qualities [7]. There are five phases that have been conducted in this bamboo chair design development adapting to the generic product development process [8].

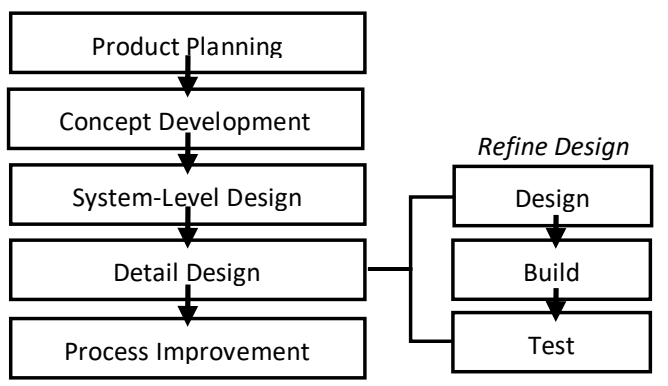

Figure 2. Product Design Development Flow Chart [8] 
The Design for Environment process has five life cycle stages that are necessary to be considered, consisting of materials, production, distribution, use, and recovery [8]. In this design study, the distribution factor becomes the main issue to solve by bamboo design development. Therefore, the design process focuses on how to reduce the product's volume to support the product shipping. This design refinement also becomes an iterative process which is done in 3 cycles and/or steps. The first step was to study the easy chair construction as the main design idea. Second, it was the refinement phase of the first model, the goal was to decrease some components. The third step focused on product volume reduction of the easy chair design. In the last phase, the newsprint was applied to the easy chair design construction and bamboo finishing process. The result of the design process was analyzed by technical requirements as the fulfillment of product design specifications [9]. Technical requirements consist of usability and manufacturing, including transportation and assembly. Prioritizing material selection over form and function is the entrance to the environmentally friendly design's application [10]. Moreover, there are two options in terms of material used for developing an environmentally friendly product, the use of natural materials and recycled materials or waste. The ecofriendly design also makes designers rethink the various materials used in the furniture, in this design study is the application of newsprint material.

\section{RESULT}

During the COVID-19 pandemic, the bamboo craft industries start to rethink how to innovate designs based on today's market trend. One of the current potential market for bamboo furniture products is still the local or regional market, especially pre-order furniture design. However, there is an opportunity to develop the bamboo furniture becomes easier to deliver and strengthening bamboo as environmentally friendly products. Bamboo product innovation also becomes the key point to dominate the market and the new material application can be an innovation strategy [11]. Besides using newsprint as waste material, the idea for developing bamboo furniture is to support the ease of product distribution. The knock-down furniture concept becomes the main direction that meets the technical requirement of the product shipping. The prototyping phase develops three chair design models. The first phase aims to know the proper bamboo furniture construction with the knockdown mechanism. These prototypes used string bamboo (Gigantochloa Apus) also known as Bambu Apus in Sleman Regency. The diameter of string bamboo is about 4-5 centimeters and it has a tight outer skin with natural color. This small diameter of string bamboo was taken from the tip of the bamboo plant. It is rarely used in many bamboo furniture workshops and considered as the secondary raw material. The following explanations are the result of the design process :

\subsection{First Prototype: The Development of Bamboo Chair Construction}

The first prototype shown in Figure 3 is divided into 6 parts of an easy chair. Part A \& B is the seat and armrest as the main structure, part $\mathrm{C}$ is a backrest, part $\mathrm{D}$ is a seat. In part C, the backrest of the easy chair is tilted $15^{\circ}$ to support the user's comfort when sitting. There are two connecting components (parts E \& F) that support the assembly of a knock-down easy chair. These two components are mounted on the front and back of the easy chair.

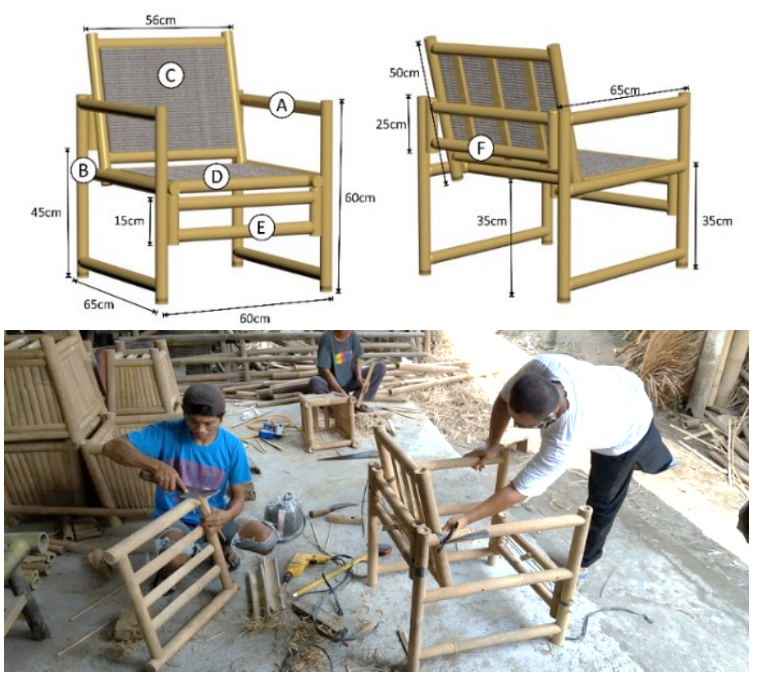

Figure 3. Dimension of Model 1 \& Prototyping Process

The working process on this first model requires a bit of accuracy due to the concept of knock-down furniture. It uses several stud bolts with a diameter of 0.8 millimeters and a length of 100 millimeters. This bamboo easy chair construction and installation also requires a high level of precision. The processing time for the first prototype takes almost one day by a welltrained bamboo craftsman. Based on the design evaluation on this prototype, there is an opportunity to reduce the number of the parts, and stud bolts, specifically on part $\mathrm{F}$ as a connecting component. Moreover, the use of stud bolts can be replaced by longer furniture bolts to make easier installation. This 
prototype also has been tried and tested by adult user with a load of about 100 kilograms.

\subsection{Second Prototype: The Decrease of Chair Component}

A second prototype was developed by reducing a connecting component (part F) of the easy chair as a main idea. Figure 4 has shown the easy chair being divided into 5 parts. The dimensions of the easy chair design are also not extremely different from the previous prototype. However, there is a slight change in the backrest design with a wider stem on the top (part C). Without part $\mathrm{F}$ installation, the number of furniture bolts on this prototype is also reduced from 16 pieces to 12 pieces. This adjustment makes the easy chair more simple, especially the view from behind the backrest. The chair assembly process is by tying between the parts during the installation of furniture bolts. The technical difficulty was the length of the drill bit which was not enough to penetrate 2 bamboo sticks measuring 5 centimeters and double drilling was required. This makes it difficult to find precision between two bolt holes and several adjustments are needed in the assembly process. Below is an overview of the model 2 assembly process:

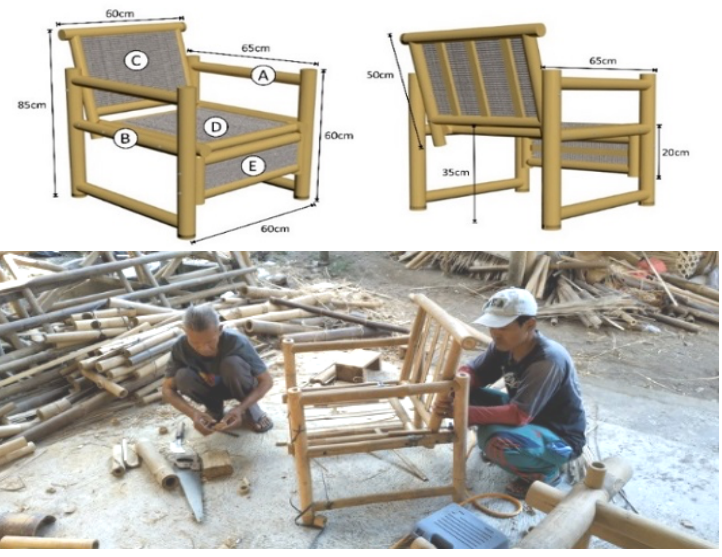

Figure 4. Dimension of Model 2 \& Prototyping Process

\subsection{Third Prototype: The Reduction of Product Volume}

The third prototype was developed by adjusting the height of the backrest component (Part C) from 50 reduced into 28 centimeters. This change is intended to cut the product volume when packing and shipping. Therefore, the product volume reduction will cut the cost of product shipping as well. It also simplified the shape of the easy chair and looked like a cube as a whole.

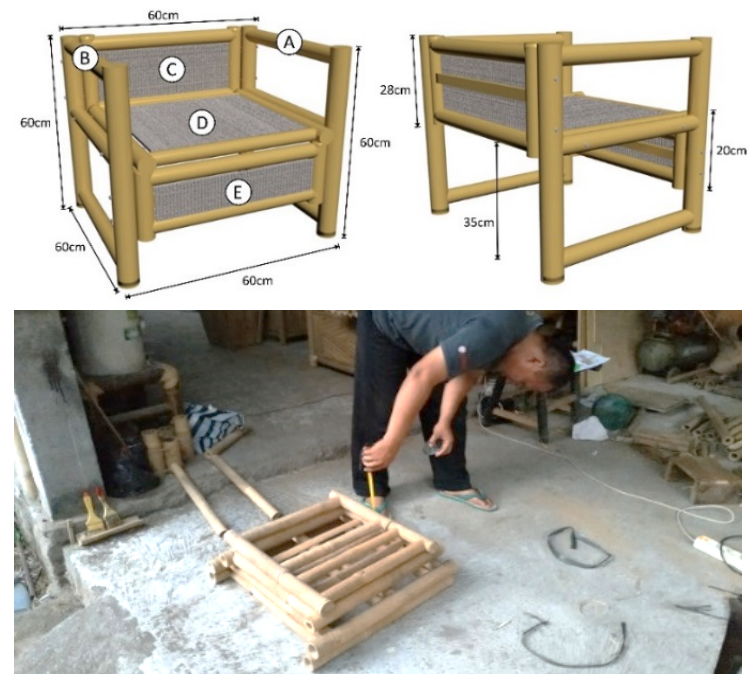

Figure 5. Dimension of Model 3 \& Measuring Product

\subsection{Application of Newspaper to Chair Design}

Used newsprint application aims to improve the bamboo furniture craft designs that have been developed in the earlier stage. Chair design development also considers the visual aspects by choosing the type of newsprint applied. It has aesthetic value and harmony with bamboo material in terms of color and texture. Used newsprint application in the bamboo chair design is done by using the rolling technique. This is a processing technique that can optimize the paper density. In addition, the rolled-up newspaper is potentially used as a structure in furniture. According to the previous research [12], the rolled-up newspaper also has good material flexibility and slight deflections when it used to withstand loads as furniture. As a natural material, bamboo also has flexural properties [13]. Besides having good strength and flexibility, the rolls of newsprint application also visually reflect an environmentally friendly impression of the product. The pictures below are the process of making and the results of newsprint rolls application: 
Table 1. The Comparison of Design Prototypes

\begin{tabular}{|c|c|c|c|c|c|}
\hline Model & Picture & Weight & Cubication & Part & Nut \& Bolt \\
\hline 1 & & $6.4 \mathrm{~kg}$ & $\begin{array}{l}\text { Dimension : } \\
\text { Length: } 70 \mathrm{~cm} \\
\text { Width : } 65 \mathrm{~cm} \\
\text { Height : } 30 \mathrm{~cm} \\
\text { Volume : } 34,1 \mathrm{KgV}\end{array}$ & 6 parts & 16 pieces \\
\hline 2 & & $6.1 \mathrm{~kg}$ & $\begin{array}{l}\text { Dimension : } \\
\text { Length: } 65 \mathrm{~cm} \\
\text { Width : } 65 \mathrm{~cm} \\
\text { Height : } 30 \mathrm{~cm} \\
\text { Volume : } 31,6 \mathrm{KgV}\end{array}$ & 5 parts & 12 pieces \\
\hline 3 & & $5.8 \mathrm{~kg}$ & $\begin{array}{l}\text { Dimension : } \\
\text { Length: } 65 \mathrm{~cm} \\
\text { Width : } 65 \mathrm{~cm} \\
\text { Height : } 25 \mathrm{~cm} \\
\text { Volume : } 26,4 \mathrm{KgV}\end{array}$ & 5 parts & 10 pieces \\
\hline
\end{tabular}

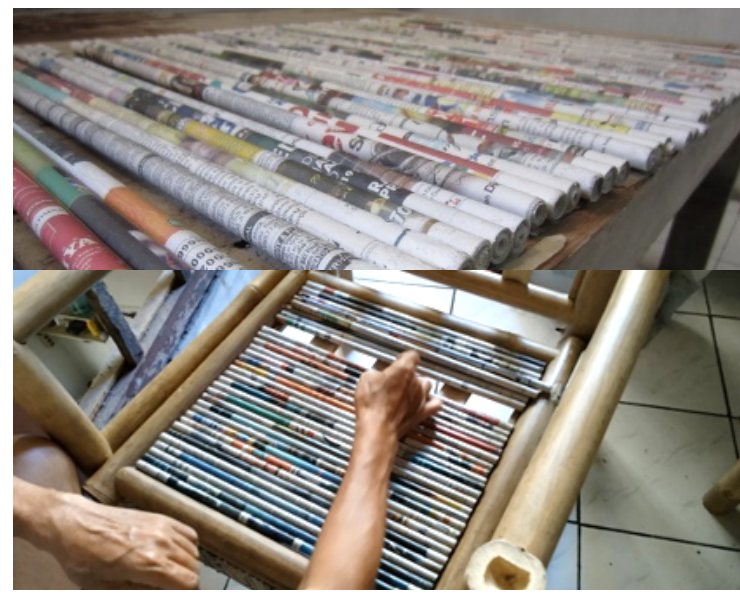

Figure 6. Rolled-up Newspaper Application

Rolls of used newsprint apllied on bamboo easy chairs are manually made by craftsmen. Each roll of newsprint consists of 2 sheets of newsprint measuring $58 \mathrm{~cm} \times 84 \mathrm{~cm}$. One stick of rolled-up newspaper has a diameter of $1 \mathrm{~cm}$ and a length of $58 \mathrm{~cm}$. In addition, this paper grammage and paper size of newsprint material refer to the Indonesian National Standard (SNI-1998).

\section{DISCUSSION}

The process of designing bamboo and newsprint chair in this study has produced 3 design variations. This design development is iterative based on several technical aspects in the evaluation process of each model. These models also have advantages and disadvantages that processed to meet the product design's objectives. Thus, the third model has several improvements that reinforce the design concept, especially to support product packing and shipping. The following table shows the comparison between the three models :

Based on the cubication measurement, there is a volume reduction of each model, as well as the parts, and the use of nuts $\&$ bolts. The bamboo chair's weight decreases along with the modules reduction which is the main component of the bamboo chair. Model 1 weights $6.4 \mathrm{~kg}$ ( 6 modules) decreases $0.3 \mathrm{~kg}$ on the results of model 2 with one module reduction on the rear component (Part F). Meanwhile, the best result with a product weight of $5.8 \mathrm{~kg}$ consisting of 5 modules and using 10 nuts and bolts is found in model 
3. In addition, product volume, which is one aspect of supporting the product delivery, also continues to decrease on design improvements. Therefore, model 3 is the ideal design development based on product volume, measured at $26.4 \mathrm{KgV}$. Besides optimizing distribution efficiency, the application of processed used newspaper on bamboo furniture will also support the issue of the design for the environment. The concept of environmentally friendly products is a strategy and approach in marketing, especially to attract consumers who pay attention to environmental issues [14].

\section{CONCLUSION}

This bamboo design development shows a new material application opportunity by the combination of a rolled-up newspaper. The use of waste newsprint on bamboo furniture will also support the design for the environment. Bamboo chair applied knock-down concept makes easier the distribution that is needed to support online market trends during pandemic COVID-19. It also inspires the innovative movements of bamboo furniture design among the SMEs in Sleman Regency. Furthermore, bamboo as the potential furniture and craft material in Sleman Regency can be combined with any recycled materials to innovate the local products.

\section{AUTHORS' CONTRIBUTIONS}

All authors conceived and designed the design study. Kristian Oentoro conducted the experiments, analyzed the data, and wrote the paper. Wiyatiningsih conducted field study and participated to manuscript revisions.

\section{ACKNOWLEDGMENTS}

We would like to convey thanks to the Institute for Research and Community Service (LPPM) Universitas Kristen Duta Wacana, Yogyakarta for supporting this research funding. The appreciation is also given to Rosse Bambu in Sleman Regency that has supported in producing our prototypes.

\section{REFERENCES}

[1] V Laemlaksakul V, S. Bangsarantrip, Analytic Hierarchy Process for Design Selection of Laminated Bamboo Chair. Proceedings of the International MultiConference of Engineers and Computer Scientists Vol II. Hong Kong; 2008. Retrieved

from: http://citeseerx.ist.psu.edu/viewdoc/download?d oi $=10.1 \cdot 1.148 .8727 \&$ rep $=$ rep $1 \&$ type $=$ pdf

[2] A.H. Putri, O.C. Dewi, Overview of Bamboo Preservation Methods for Construction Use in Hot Humid Climate. International Journal of Built Environment and Scientific Research; 2020: 4 (1). pp. 1-10. DOI: https://doi.org/10.24853/ijbesr.4.1.1-10

[3] I. Rijaya, Fitmawati, Jenis-Jenis Bambu (Bambusoideae) di Pulau Bengkalis, Provinsi Riau, Indonesia. Journal of Floribunda; 2019: 6 (2) pp. 41-52. DOI: https://doi.org/10.32556/floribunda.v6i2.2019.2 29

[4] Pemerintah Kabupaten Sleman. Bambu Menjadi Komoditas Unggulan Sleman. Online Article; 2013. Retrieved from: http://www.slemankab.go.id/5329/bambumenjadi-komoditas-unggulan-sleman.slm

[5] D. Yosky, S.R. Budiani, Determinan Lokasi Sentra Industri Kerajinan Bambu Di Kabupaten Sleman. Jurnal Pembangunan Wilayah dan Kota. Semarang: UNDIP 2019: 15 (4), pp.301-309. DOI: https://doi.org/10.14710/pwk.v15i4.20594

[6] K. Oentoro, T.T. Putro, Penerapan Kertas Semen Bekas dalam Struktur Desain Kursi dengan Teknik Laminasi Pipa. Proceedings of Seminar Nasional Aplikasi Sains \& Teknologi (SNAST); 2018. pp. 415-425. Retrieved from: https://journal.akprind.ac.id/index.php/prosiding snast/article/view/1459

[7] C.A. Sörensen, A Material Framework for Product Design; 2018. Sweden: Faculty of Engineering and Department of Design Sciences, Lund University. Retrieved from: https://www.divaportal.org/smash/get/diva2:1404370/FULLTEX T01.pdf

[8] K.T. Ulrich, S.D. Eppringer, M.C. Yang. Product Design and Development (Seventh Edition); 2019. New York: McGraw-Hill Education.

[9] C. Ciupan, E. Pop, I. Filip, E. Ciupan, E. Câmpean, I. Cionca, V. Heres, A new approach of the design process for replacing wooden parts of furniture. Proceedings of MATEC Web of Conferences 137; 2017. Romania: EDP Sciences. pp. $1-7$. DOI: https://doi.org/10.1051/matecconf/20171370600 2 
[10] E. Yüksel, M. Kiliç, Eco-friendly approach in furniture design. Proceedings of the 27th International Conference: Research for Furniture Industry; 2015. pp. 357-368. Retrieved from: https://furnituredesign2015.org/assets/icrfi_tr_1 58.pdf

[11] V. Laemlaksakul, S. Bangsarantrip, Analytic Hierarchy Process for Design Selection of Laminated Bamboo Chair. Proceedings of the International MultiConference of Engineers and Computer Scientists Vol II. Hong Kong; 2008. Retrieved

from: http://citeseerx.ist.psu.edu/viewdoc/download?d $\mathrm{oi}=10.1 .1 .148 .8727 \& \mathrm{rep}=$ rep $1 \&$ type $=$ pdf

[12] K. Oentoro, Eksperimen Pengembangan Desain Furnitur Berbahan Kertas Koran Bekas. Master of Design Thesis Report; 2012. Bandung: FSRD ITB.

[13] D. Trujillo, S. Jangra, J.M. Gibson, Flexural properties as a basis for bamboo strength grading. Proceedings of the Institution of Civil Engineers; 2016. UK: Institution of Civil Engineers Publishing. pp.1-12. DOI: https://doi.org/10.1680/jstbu.16.00084

[14] Y.K. Yan, R. Yazdanifard, The Concept of Green Marketing and Green Product Development on Consumer Buying Approach. Global Journal of Commerce \& Management Perspective; 20143 (2) pp.33-38. Retrieved from: https://www.longdom.org/articles/the-conceptof-green-marketing-and-green-productdevelopment-on-consumer-buying-approach.pdf 